\title{
IMPACT OF CREDIT RISK MANAGEMENT SYSTEMS ON THE FINANCIAL PERFORMANCE OF COMMERCIAL BANKS IN UGANDA
}

\author{
Isah Serwadda ${ }^{1}$ \\ ${ }^{1}$ Department of Finance, Faculty of Business and Economics, Mendel University, Zemědělská 1, 61300 Brno, \\ Czech Republic
}

To cite this article: SERWADDA ISAH. 2018. Impact of Credit Risk Management Systems on the Financial Performance of Commercial Banks in Uganda. Acta Universitatis Agriculturae et Silviculturae Mendelianae Brunensis, 66(6): 1627-1635.

To link to this article: https://doi.org/10.11118/actaun201866061627

\begin{abstract}
The paper is set to analyse the impact of credit risk management on the financial performance of commercial banks in Uganda for a period of 2006-2015 using panel data for a sample of 20 commercial banks. The study employs return on assets as a dependent variable and non-performing loans, growth in interest earnings and loan loss provisions to total loans as credit risk measures. Secondary data is sourced from the Bank scope database, African development bank and the central bank of Uganda. The study employs descriptive statistics, regressions and correlation analysis. Regression models are to estimate the magnitude of significance of credit risk management on the performance of commercial banks in Uganda.

The study revealed that credit risk management impacts on the performance of Ugandan commercial banks. The results portrayed that banks' performance was inversely influenced by non-performing loans which may expose them to large magnitudes of illiquidity and financial crisis. Thus given such results, the researcher recommends that banks need to enhance their credit risk management techniques not only to earn more profits but also to maintain a qualitative asset portfolio and attention be given to non-performing loans, loan loss provision to total loans and growth in interest earnings that were found to be significant.

Banks need to design appropriate credit policies that must handle all necessary conditions before advancing credit to their customers and also develop strong credit administration committees and teams that must conduct appropriate and sound loan appraisal evaluations and which must also monitor the loans throughout the required processes right from extending a loan to a customer up to the completion of loan repayments so as to mitigate credit risks.
\end{abstract}

Keywords: loan provisions, non-performing loans, credit risk

\section{INTRODUCTION}

Credit remains the core source of income for any bank across the globe (Kargi, 2011) though it exposes banks to credit risk. The Basel committee on banking supervision (2001) defines credit risk as the probability of losing an outstanding loan amount partially or wholesomely due to different credit events (default risk). Hence, the more a bank is exposed to credit risk, the higher the probability of experiencing financial distress and vice versa.

The efficient and excellent performance of the banking sector is a reflection of excellent financial stability in a country (Sufian and Chong, 2008). Banks provide credit, and this intermediation function is observed as a vehicle for economic growth and its long-term sustainability. Banks 
incur quite some risks, and among them, credit risk plays an essential role in determining their profitability since a more significant portion of their revenue accrues from the interest charged on loans. This results in interest rate risk which is directly connected to credit risk, and this implies that an increase in interest rates raises the probability of loan default.

Credit risk and interest rate risk are intrinsically linked to each other (Drehman et al., 2008). The occurrence of increased non-performing loans in a loan portfolio deters banks from achieving their goals. Non-performing loans are the percentage of loan amounts that are not serviced for three months and above (Ahmad and Ariff, 2007).

Thus, the increased non-performing loans raised concerns, and the Basel 11 Accord stressed the need for proper credit risk management practices which ultimately improves bank performance. Hence the effective management of credit risk of banks will not only uphold the viability and profitability of their businesses but also supports the systemic stability and the efficient allocation of capital in an economy (Psillaki et al., 2010).

Efficient and effective risk management is ideal for the survival of banks as it enables them to allocate resources to risk units considering a trade-off between risk and return on investments (Ogbol and Okallo, 2013). Mekasha (2001) examined credit risk management and its effects on performance of Ethiopian commercial banks. The study investigated the relationship between return on assets and loan provision, non-performing loans and total assets which found that there was a significant relationship between bank performance and credit risk management

Given a couple of risks faced by banks, management of credit risk is always given particular attention since losses incurred on loans directly affect banks profitability. Thus sound credit risk management policies maximise banks' performance by handling credit risk exposure within the acceptable standards. Banks usually monitor closely and conduct rigorous credit analysis of counterparties and different products. To up the game, banks have also worked hard on improving their forecasting abilities to ascertain risk in stressed market conditions.

More so, regulatory authorities have always encouraged banks to observe credit risk analysis closely and also conduct periodic audits regularly. The central bank of Uganda put in place an oversight surveillance capacity system through which new techniques of risk-based supervision are employed (Bank of Uganda supervision report, 2010). It conducts off-site and onsite activities to examine banks' performance to contain risk.

\section{Status of the banking sector in Uganda}

Banks' performance in Uganda has shrunk in the past years due to increased loan defaults, fraud cases, and liquidation of some banks. In 2012,
Bank of Uganda closed down the National Bank of Commerce, an indigenous commercial bank owned by private native investors. Its assets were liquidated to Crane Bank, under the command and control of the Bank of Uganda (Rupiny, 2012).

Additionally, the industry has passed through some transitions especially in early 2000; it significantly experienced restructuring as some commercial banks were publicly declared insolvent and finally liquidated out by Bank of Uganda. Hence such experience resulted in the passing of the 2004 legislative bill. After that, enacted and termed as "The Financial Institutions Act - 2004" upon financial institutions in which new governance and compliance guidelines were designed to help bolster the financial sector and credit risk management inclusive based on principles of corporate governance, transparency and accountability.

Thus in 2008-2009, numerous existing institutions experienced massive branch expansion through mergers and acquisitions. It resulted in tremendous growth in the banking industry in Uganda recorded ever.

The paper intends to examine the relationship between return on assets (ROA) as a dependent variable and non-performing loans (NPL), growth in interest earnings (GIE), loan loss provision/total loans (LLP) as independent variables.

This paper is set to investigate the impact of credit risk management on the financial performance of commercial banks and also to contribute to the literature gap in Uganda since several studies on credit risk have been conducted elsewhere other than Uganda.

This paper is structured in a way that; the first section of the article covers the introduction, the second covers related literature review, the third section covers methodological approaches and the variables description, the fourth covers the discussion and interpretation of results and the last section concludes with possible recommendations.

\section{Related literature review}

Credit risk is one of the cardinal exposures that banks incur while extending credit to their customers since credit is considered as the main source of revenue to banks (Fan and Yijun, 2014). Credit risk is the risk where a borrower defaults and does not observe his or her obligations to settle a debt as per the agreed contractual time (Gestel and Baesens, 2008).

Credit risk management is the system of mitigating losses by analysing the adequacy of banks' capital and loan loss reserves at any time, and this process has continued to be a great challenge in the contemporary world (Singh, 2013).

There are several empirical studies on the effect of credit risk upon bank performance, and most of these findings assert that there is a positive contribution on bank performance as others suggests a negative one as the preceding discussion; 
Aduda and Gitonga (2011) identified that credit risk affected profitability to a given level. Boahene, Dasah and Agyei (2012) investigated the relationship between credit risk and banks' profitability and identified a positive relationship between credit risk and profitability.

Hakim and Neaime (2001) analysed the effect of credit, liquidity and capital on bank performance of Egyptian and Lebanese banks and realised that there was a sound risk management status of compliance and procedural systems. Aruwa and Musa (2014) examined the effects of credit risk and other risk components on banks' financial performance in Nigeria, and they realised a strong relationship between credit risk and banks' financial performance.

Hosna et al., (2009) identified that non-performing loans affected banks' performance as measured by return on equity more than capital adequacy ratio. Kurawa and Garba (2014) stressed that credit risk management indicators affected banks' profitability.

Poudel (2012) analysed the different credit risk management factors and observed that most dominant factors were the default rate. Nawaz and Munir (2012) realised that credit risk management affected banks' profitability and recommended that management should design credit risk management policies that may not adversely affect profitability. Abderahim (2013) realised that liquidity and bank size affected the effectiveness of credit risk management significantly. Adeusi et al., (2013) stressed that risk management indicators like capital asset ratio, doubtful loans affected banks' performance.

Ruwani and Nimal (2013) analysed the effect of overall credit risk management on Sri Lankan banks' performance and realised that the mean efficiency of Sri Lankan banks is higher compared to other banks elsewhere like UK, USA, India, and Taiwan among others. The study also observed that risk management strategies significantly improved considerably the efficiency of licensed banks in Sri Lanka.

Ogbol and Okallo (2013) investigated the effect of credit risk management on capital adequacy and financial performance of banks in Nigeria. Panel data model was employed to determine the relationship that exists between return on assets and the credit risk indicators like loan loss provision, loans and advances, capital adequacy. Findings portrayed that sound credit risk management and capital adequacy affected positively the performance of banks except for loans and advances which reflected a negative effect on performance.

Dhakal(2015) realised that capital had negative and significant relation with provision for loan loss, as there was no significant relationship between bank size, GDP growth rate and inflation with provision for loan loss. Shrestha (2014) realised that return on assets, capital adequacy ratio, return on equity and net interest margin have a significant positive relationship with non-performing loans though the ratio of total loans to total deposits and logarithms of total assets have a negative relation with non-performing loans.

The above empirical findings portray that the effect of credit risk on the performance of banks in different countries has been of considerable influence, though there are no such findings with the help of recent data in the context of Uganda.

Hence this paper is set to examine the relationship between credit risk management and performance of commercial banks in Uganda and also to contribute and improve on some of the existing research works as it employs some credit risk management and performance metrics.

\section{MATERIALS AND METHODS}

The study is based on secondary data got from the Bank scope database, African development bank and the central bank of Uganda for 2006-2015 using a sample of twenty commercial banks out of twenty-five commercial banks in Uganda (Bank of Uganda report, 2016) for a ten year period.

Panel regression model is employed to ascertain the impact of credit risk management factors using non-performing loans, growth in interest earnings, and loan loss provision to total loans as independent variables on commercial banks' performance in Uganda using return on assets as a dependent variable.

In other words, the study employs panel data analysis for its estimations that requires particular techniques that cater for time series and a cross-section dimension of the data. This is adopted in order to determine the magnitude of independent variables on return on assets. Hence the study uses fixed and random effects techniques for estimation and thereafter adopts the Hausman specification test to identify the appropriate technique for analysis.

The fixed effects technique accounts for the difference in the cross-section units by assuming different constant term for each bank. However, the random effects model assumes that individual specific effects vary randomly across sections.

The study also employs descriptive statistical analysis to establish the impact of credit risk management factors on profitability, and it also employs correlation matrix to estimate the level of correlations between the independent variables and profitability of commercial banks.

Variation Inflation Factor is employed to test for multicollinerity problems and the Augmented Dickey-Fuller test was also carried out to determine for the stationality of the variables employed. The current study selected the variables following the variables applied in the contemporary empirical research works elsewhere to find out whether they have an economic effect on Uganda's commercial banks as per credit risk management is concerned. Hence, their application in the model. 


\section{Model specification}

This study is modelled and follows the works of Kolapo, Ayeni and Oke (2012), Hosna, Manzura and Juanjuan (2009), Kithinji (2010), Poudel (2012) that examined the effect of credit risk and commercial banks' performance. Below is the model;

$R O A=F\left(\beta_{0}+\beta_{1} \frac{N P L}{L A_{i t}}+\beta_{2} \frac{L L P}{C L}+\beta_{3} \frac{L A}{T D_{i t}}+\beta_{4} \frac{E Q}{T A_{i t}}+\right.$ $\left.+\beta_{5} \frac{T D}{L A_{i t}}+\varepsilon_{i t}\right)$

Where, $\quad R O A=$ Return on Assets, $N P L=$ = Non-performing loans, $L A=$ Loans and advances, $L L P=$ Loan Loss Provision, $C L=$ Classified Loans, $T D=$ Total $\quad$ Deposit,$\quad E Q=$ Shareholders' Funds TA $=$ Total Assets.

The equation can be rewritten as below with the following model;

$$
R O A=\beta_{0}+\beta_{1} \frac{N P L}{T L}+\beta_{2} G I E_{i t}+\beta_{3} \frac{L L P}{T L}+\varepsilon_{i t}
$$

Where $R O A=$ Return on Assets, NPL = $=$ Non-performing loans, $T L=$ Total loans, GIE $=$ $=$ Growth in interest earnings $=\frac{L A}{T D} \mathrm{LA}=$ Loans and advances, $\mathrm{TD}=$ Total deposits, $\mathrm{LLP}=$ Loan loss Provision, $\varepsilon_{i t}=$ Error term.

However, the current study considers three variables for investigations, see equation 2 unlike in the previous works of Kolapo, Ayeni and Oke (2012), Hosna, Manzura and Juanjuan (2009), Kithinji (2010), Poudel (2012) who used five variables as in equation 1. However, after conducting multicollinerity tests some 2 variables had strong correlations and hence dropped, therefore the study decided to maintain the use of only 3 independent variables in its investigations.

The model takes the following equation;

$R O A=\beta_{0}+\beta_{1} X_{i t}+\varepsilon_{i t}$

Where, $i$ represent the cross-sectional dimension and $t$ representing time-series dimension. Meanwhile, $R O A$ is the dependent variable which is the return on assets ratio,

$X_{i t}$ Represents a composition of independent variables, $\varepsilon_{i t}$ represents the stochastic error term for the bank, $i$ at the time, $t$ in an estimation model. Both methods of panel data are applied, and that is fixed effects and random effects models.

\section{RESULTS}

From Tab. III, the probability figures of the variables under scrutiny namely NPL, LLP and GIE are, extremely small less than 0.005 and hence greatly significant. The results of panel data in Tab. iii portray that all the coefficients are individually statistically significant. The two slope coefficients

I: Variables definition and units of measurements

\begin{tabular}{lccc}
\hline Number & Abbreviation & Description & Measurement unit \\
\hline $\mathbf{1}$ & ROA & Return on Assets & Net income/ Total Assets \\
$\mathbf{2}$ & NPL & Non-performing loans & $\begin{array}{c}\text { Percentage of non-performing loans out of } \\
\text { total loans }\end{array}$ \\
$\mathbf{4}$ & LLP & Loan Loss Provision & $\begin{array}{c}\text { Percentage of loan loss provision out of total } \\
\text { loans }\end{array}$ \\
\hline
\end{tabular}

II: Unit Root Test Table - Some variables that were non-stationary, first-order differences were done to stationarize them as below, where $\Delta$ means first order difference.

\begin{tabular}{lccc}
\hline \multicolumn{1}{r}{ Variable } & p-value at level & p-value after first order difference & Decision \\
\hline SROA & 0.094 & 0.0000 & $\mathrm{I}(1)$ \\
NPL & 0.003 & & $\mathrm{I}(0)$ \\
LLP & 0.002 & & $\mathrm{I}(0)$ \\
$\boldsymbol{\Delta}$ GIE & 1.000 & 0.000 & $\mathrm{I}(1)$ \\
\hline
\end{tabular}

Source: Authors calculations from STATA, 2018

III: Fixed effects model

\begin{tabular}{lcccc}
\hline \multicolumn{1}{c}{ ROA } & Coefficient & Standard. Error & Z-statistics & P-Value \\
\hline NPL & -21.78407 & 4.711453 & -4.62 & 0.000 \\
LLP & 38.3329 & 12.56455 & 3.05 & 0.003 \\
GIE & 0.9926356 & 0.1359286 & 7.30 & 0.000 \\
Constant & -11.20561 & 1.637091 & -6.84 & 0.000 \\
\hline
\end{tabular}

Source: Authors calculations from STATA, 2018 
have positive signs namely loan loss provision (LLP) and growth in interest earnings (GIE) and only one with a negative sign and that is non-performing loans (NPL).

- $\mathrm{b}=$ consistent under Ho and Ha; obtained from xtreg; where, Ho is Null hypothesis and $\mathrm{Ha}$ is Alternative hypothesis

- $\mathrm{B}=$ inconsistent under $\mathrm{Ha}$, efficient under Ho; obtained from xtreg.

Test: Ho: difference in coefficients not systematic

- Prob $>$ chi $2=0.0010$, Ha decision taken

The Hausman test was conducted (see results of Tab. IV) which showed that fixed effects model is the appropriate model for the study

The Hausman test examines the null hypothesis that coefficient determined by the random effects estimator is the same as the one estimated by the fixed effects estimator.

Hence, if Hausman test is insignificant (prob > Chi2 is greater than 0.05, then fixed effects model is applied and the appropriate model for the study and random effects model is rejected (Torres-Reyna, 2007).

The fixed effects model is estimated in Tab. V as below.

Since the Hausman test chose fixed effects model, hence the study applied this very model and above are the results in Tab. V.

Tab. V indicates that there is a significant relationship, i.e the default rate relationship between the dependent variable, return on assets (ROA) and all the independent variables namely non-performing loans (NPL), loss provision to total loans (LLP) and growth in interest earnings (GIE). Thus the results portray that all the risk management variables have a direct relationship with performance. From the Tab. V above, the results indicate that a unit change in the default rate, for example, if the non-performing loans increase by $1 \%$, then return on assets (profitability) will decrease by $21.78 \%$. Similarlryl $\%$ increase in loan loss provision will imply $38.33 \%$ increase in profitability and vice-versa. And finally, $1 \%$ increase in growth in interest earnings will imply $0.99 \%$ increase in profitability and vice-versa.

The notable standard deviation of credit risk factors illustrates that credit risk management quality varies among the different Ugandan commercial banks.

There is also a variation among the commercial banks in loan loss provision which is evidenced by the standard deviation of $0.0376458 \%$.

The non-performing loans of these banks is varied from -35.98 to 35.345 with a mean and standard deviation of $0.0043471 \%$ and $0.1007344 \%$ respectively which implies that there is high volatility among banks' capacity in credit risk management.

The mean of ROA is $1.239856 \%$ which means that banks are competing amongst themselves when making profits and their standard deviation is also evident that their profit-making capacity is divergent from each other at $7.5186 \%$.

IV: Hausman specification test Coefficients

\begin{tabular}{lcccc}
\hline & $(\mathbf{b})$ & $(\mathbf{B})$ & $(\mathbf{b}-\mathbf{B})$ & sqrt(diag(V_b-v_B $)$ ) \\
\hline Variables & $(\mathrm{Fe})$ & $(\mathrm{Re})$ & (Difference) & \\
NPL & -21.78407 & -19.05138 & -2.732695 & 1.652516 \\
GIE & 0.9926356 & 1.10595 & -0.1133141 & 0.0291245 \\
LLP & 38.3329 & 22.13132 & 16.20159 & 3.872424 \\
\hline
\end{tabular}

Source: Authors calculations from STATA, 2018

V: Fixed effects model

\begin{tabular}{lcccc}
\hline \multicolumn{1}{c}{ ROA } & Coefficient & Standard. Error & Z-statistics & P-Value \\
\hline NPL & -21.78407 & 4.711453 & -4.62 & 0.000 \\
LLP & 38.3329 & 12.56455 & 3.05 & 0.003 \\
GIE & 0.9926356 & 0.1359286 & 7.30 & 0.000 \\
Constant & -11.20561 & 1.637091 & -6.84 & 0.000 \\
\hline
\end{tabular}

Source: Authors calculations from STATA, 2018

VI: Descriptive statistics results

\begin{tabular}{cccccc}
\hline & Observations & Mean & Std.dev & Min & Max \\
\hline ROA & 200 & 1.239856 & 7.51861 & -35.98 & 35.345 \\
NPL & 200 & 0.0043471 & 0.1007344 & -0.551783 & 0.2279853 \\
LLP & 200 & 0.0189503 & 0.0376458 & -0.0660715 & 0.1921454 \\
GIE & 200 & 11.9014 & 3.291782 & 3.45612 & 34.64592 \\
\hline
\end{tabular}

Source: Authors calculations from STATA, 2018. 
The mean of growth in interest earnings is $11.9014 \%$ implying that Ugandan commercial banks collect higher interest on loans granted.

In an attempt to determine the nature of the correlation between dependent and independent variables and also estimate whether or not multicollinerity exists as an effect of the relationship among the variables, Tab. VII is prepared for this role. The correlation matrix from Tab. VII gives an account in which the independent variables are related to ROA.

From the Tab. VII the diagonal values are all 1.0000 implying that each value is perfectly correlated with itself. More so from the Tab VII the highest correlations are 0.5169 for GIE and 0.2496 for LLP; these correlations are positive meaning that as the values of GIE and LLP increase, banks' profitability will also increase. On the other hand, NPL has a negative correlation of -0.3036 which means as the value of NPL increases, then profitability decreases.

Furthermore, Tab. VII portrays that the independent variables are not highly correlated since their correlation coefficients are less than 0.7. Wooldridge (2015) states that multicollinerity exists if the correlation coefficient is higher than 0.7 and according to the results presented in Tab. VIII, they indicate that there is no high correlation amongst the variables, an impression that multicollinerity is not existing. Relationships among the independent variables are positive except those that exist between NPL and other independent variables.

To further examine the validity of non-multi-collinearity in the model, the study employs tolerance value (TV) and variation inflation factor (VIF) as a test to check for the presence of multicollinerity as below in Tab. VIII.

From the Tab. VIII, TV ranges from 0.894444 to 0.915198 that suggests a non-multi-collinearity character. Nachane (2006) asserted that VIF less than 10.0 is acceptable. Important to note is that VIF is just a reciprocal of TV and in this case the VIF in Tab. VIII ranges from 1.09 to 1.12 and thus this implies the absence of multicollinerity.

\section{DISCUSSION}

In this present study, it's observed that there is a significant relationship between credit risk management indicators and banks' performance as measured by return on assets (ROA).

There is a negative significant relationship between non-performing loans and banks' performance (ROA). The results portray that increase in non-performing loans reduces profitability by $21.8 \%$. The study findings illustrate that there is an inverse relationship between return on assets and non-performing loans. This implies that based on the study results; non-performing loans are paramount in influencing the asset quality of Ugandan commercial banks. It also further suggests that profits after taxes have been reactive to the credit policy of these commercial banks. These results are in harmony with those of Kolapo, et al. (2012); Kargi (2011); Kodithuwakku (2015).

However, these findings do not conform to those of Boahene, Dasah and Agyei (2012); Fan and Yijun (2014) who observed those non-performing loans and other credit risk factors have a positive effect on bank performance.

There is a significant and positive effect of loan loss provision to total loans on banks' performance. From a theoretical perspective, loan loss provision should affect the bank's profitability negatively; unfortunately, the study realised a positive correlation coefficient which signifies performance of banks positively. These results conform to those of (Matewos et al., 2013).

In principle and practice, credit risk managers appreciate the risk arising from lending business and hence tighten their credit risk management capacity while incorporating high loan loss provision that could generate high profits. This is because loan loss reserves act as a buffer against loan loss. The working assumption behind loan loss provision is

VII: Correlation matrix

\begin{tabular}{lcccc}
\hline & ROA & NPL & GIE & LLP \\
\hline ROA & 1.0000 & & & \\
NPL & -0.3036 & 1.0000 & & \\
GIE & 0.5169 & -0.0499 & 1.0000 & 1.0000 \\
\hline LLP & 0.2496 & -0.2381 & 0.1680 & \\
\hline
\end{tabular}

Source: Authors calculations from STATA, 2018

VIII: Results of TV and VIF for credit risk management factors

\begin{tabular}{lcc}
\hline & VIF & I/VIF(TV) \\
\hline NPL & 1.09 & 0.915198 \\
GIE & 1.11 & 0.899965 \\
LLP & 1.12 & 0.894444 \\
\hline
\end{tabular}

Source: Authors calculations from STATA, 2018 
that managers through this provision create avenues towards bank asset quality management.

There is a significant and positive relationship between growth in interest earnings on loans and advances and ROA. These results conform to those of Marshal and Onyekachi (2014), Kolapo, et al. (2012). However, these results are contrary to those of Ogbol and Okallo (2013) who found that loans and advances reflected a negative effect on performance.

These findings are also in conformity with the results of Abiola and Olausi (2014) plus those of Adeusi, Akeke, Adebisi and Olandunjoye (2013) who stressed an effect of credit risk management on performance as measured by return on equity (ROE) and return on assets (ROA).

\section{CONCLUSIONS}

From the present study, the study intends to analyse the impact of credit risk management on the performance of banks with the help of credit risk management aspects and financial performance metric or measure.

Hence, the prevailing empirical results show that credit risk key factors include growth in interest earnings; non-performing loans and loan loss provision to total loans affect the profitability of Ugandan commercial banks as measured by ROA.

From the above empirical findings, the study concludes that credit risk management factors as analysed are crucial factors in determining the profitability of Ugandan commercial banks and hence banks should pay more attention to them. For instance, these results showed that banks' performance was inversely influenced by non-performing loans which may expose them to large magnitudes of illiquidity and financial crisis.

Hence, the study recommends that Ugandan banks should design effective strategies to deal with credit risk management issues accordingly. This is because poor credit risk management policies affect banks' performance adversely as they impact on asset quality which eventually results in increased loan losses plus non-performing loans thereby exposing banks to financial distress.

Banks should create efficient management systems by working under good credit environments with strong loan evaluations, loan granting processes, establishing efficient credit administration control systems for constant monitoring and flow of the entire loan processes right from credit applications to disbursements and throughout the whole repayment cycles or loan tenures to be able to compete favorably.

Moreover, from an empirical and theoretical point of view, credit risk is not severe as it has been stressed that the greater the risk, the greater the return due to the banks' capacity to increase their credit portfolios though banks need to balance and mitigate the credit risks associated with a degree of return. Thus, in this case, banks should endeavour to hold some amounts of capital reserves to be able to contain credit risk in the event of a financial crisis.

Hence strong credit risk management committees should be established, so that appropriate credit risk management decisions are made to enhance the profitability of banks.

The Ugandan central bank should design policies and tools to effectively monitor and examine the lending atmosphere of the commercial banks in the market.

Findings of this paper can be applied to policy recommendations by credit risk managers when handling credit risk management decisions in Uganda and the entire world.

\section{Acknowledgements}

I gratefully acknowledge the comments of Zuzana Kučerová on the previous versions of the paper. "This research was funded by Internal IGA project no.PEF_TP_2018006 at Mendel University, Faculty of Business and Economics"

\section{REFERENCES}

ABDELRAHIM, K. E. 2013.The effectiveness of credit risk management of Saudi banks in the light of global financial crisis: A qualitative study. Asian Transactions on Basic and Applied Sciences, 3(2): 73-91.

ABIOLA, I. and OLAUSI, A. S. 2014.The impact of credit risk management on the commercial banks' performance in Nigeria. International Journal of Management and Sustainability, 3(5):295-306.

ADEUSI, S. O., AKEKE, N. I., ADEBISI, O. S. and OLANDUJOYE, O. 2013. Risk management and financial performance of Nigerian banks. Journal of Business and Management, 14(6): 52-56.

ADUDA, J. and GITONGA, J. 2011. The relationship between profitability and commercial banks in Kenya. Journal of Modern Accounting and Auditing, 7(9): 934-946.

AMHAD, N. H. and ARIFF, M. 2007.The multi-country study of risk determinants. International Journal of Banking and Finance, 5(1): 135-152.

ARUWA, S. A. and MUSA, O. A. 2014. Risk components and financial performance of deposit money in Nigeria. International of Journal of Social Sciences and Entrepreneurship, 1(11): 1-8. 
BANK OF UGANDA. 2010. Annual supervision report 2010. Bank of Uganda. [Online]. Available at: https:// www.bou.or.ug/bou/bou-downloads/asr/2010/Dec/ASR_Dec_2010.pdf [Accessed: 2018, September 15].

BANK OF UGANDA. 2013. Annual supervision report 2013. Bank of Uganda. [Online]. Available at: https:// www.bou.or.ug/bou/bou-downloads/asr/2013/Dec/Annual-Supervision-Report-2013.pdf [Accessed: 2018, September 15].

BANK OF UGANDA. 2016. Annual supervision report 2016. Bank of Uganda. [Online]. Available at: https:// www.bou.or.ug/bou/bou-downloads/asr/2016/Dec/Annual-Supervision-Report-December-2016--FINAL-COPY.pdf [Accessed: 2018, September 15].

BASEL COMMITTEE ON BANKING SUPERVISION. 2001. Risk management practices and regulatory capital: Cross-sectional comparison. The Joint Forum. Available at: https://www.bis.org/publ/joint04.pdf [Accessed: 2018, September 15].

BOAHENE, S.H., DASAH, J. and AGYEI, S. K. 2012. Credit risk and profitability of selected banks in Ghana. Research Journal of Finance and Accounting, 3(7): 6-15.

DHAKAL, B. 2015.The determinants of loan loss provision in Nepalese commercial banks, Kathmandu. Journal of Banking and Finance, 30(2): 220-240.

DREHMAN, M., SORENSEN, S. and STRINGA, M. 2008. The integrated impact of credit and interest rate risk on banks. An economic and capital adequacy perspective. Working paper, no. 339. The Bank of England.

FAN, L. and YIJUN, Z. 2014. The impact of credit risk management on the profitability of commercial banks: A study of Europe. Umea school of business and economics.

GESTEL, T. V and BAESENS. B. 2008. Credit risk management basic concepts: Financial risk components, rating analysis, models, economic and regulatory capital. Oxford University Press.

HAKIM, S. and NEAIME, S. 2001. Performance and credit risk in banking, a comparative study for Egypt and Lebanon. ERS Working Papers Series, No. 137. ERF.

HOSNA, A., MANZURA, B. and JUANJUAN, S. 2009. Credit risk management and profitability in commercial banks in Sweden. Master Thesis. University of Gothenburg.

KARGI, H. S. 2011. Credit risk and performance of Nigerian banks, department of accounting, faculty of administration. Zaria: Ahmadu Bello University.

KITHINJI, A. M. 2010. Credit risk management and profitability of commercial banks in Kenya. Working Paper. Nairobi: School of Business, University of Nairobi, Kenya.

KODITHUWAKKU, S. 2015. Impact of credit risk management on the performance of commercial banks in Sri Lanka. International Journal of Scientific Research and Innovative Technology, 2(7): 1-6.

KOLAPO, T. F., AYENI, R. K. and OKE, O. 2012. Credit risk management and performance of commercial banks in Nigeria, A panel model approach. Austrian Journal of Business and Management Research, 2(2): 31-38.

KURAWA, J. M. and GARBA, S. 2014. An evaluation of the effect of credit risk management on the profitability of Nigerian commercial banks. Journal of Modern Accounting and Auditing, 10(1): 104-115.

MARSHAL, I. and ONYEKACHI, O. 2014. Credit risk and performance of selected deposit money banks in Nigeria: an empirical investigation. European Journal of Humanities and Social Sciences, 31(1): 1684-1694.

MEKHASHA, G. 2001. Credit risk management and performance of commercial banks in Ethiopia. Addis Ababa University.

MILLION, G., MATEWOS, K. and SUJATA, S. 2013. The impact of credit risk on profitability performance of commercial banks in Ethiopia. African Journal of Business Management, 9(2): 59-66.

NACHANE DILIP, M. 2006. Econometrics: Theoretical foundations and empirical perspectives. New Delhi: Oxford university press.

NAWAZ, M. and MUNIR, S. 2012.Credit risk and performance of Nigerian commercial banks. Interdisciplinary Journal of Contemporary Research, 4(7): 49-63.

OGBOL, C. and OKALLO, K.U. 2013. Impact of credit risk management and capital adequacy on the financial performance of commercial banks in Nigeria. Journal of Emerging Issues in Economics, Finance and Banking, 2(3): $703-717$.

POUDEL, R. P. 2012. The impact of credit risk management on the financial performance of commercial banks in Nepal,.International Journal of Arts and Commerce, 1(5): 9-15.

PSILLAKI, M., TSOLAS, I. E. and MARGARITIS, D. 2010. Evaluation of credit risk based on firm performance. European Journal of Operational Research, 201(3): 873-888.

RUPINY, D. 2012. BoU: National bank of commerce was in a financial mess. Uganda radio network

RUWANI FERNANDO, J. M. and NIMAL, P. D. 2013. Does risk management affect bank efficiency? an analysis of the Sri Lankan banking sector. Economics papers. Orebro University, school of business.

SHRESTHA, D. 2014.The relationship between risk and capital in commercial banks, Journal of Banking and Finance, 16(2): 439-457.

SINGH, A. 2013. Credit risk management in Indian commercial banks, International Journal of Marketing, Financial Services and Management Research, 2(7):47-51.

SUFIAN, F. and CHONG, R. R. 2008. Determinants of bank profitability in a developing economy: Empirical evidence from the Philippines, Asian Academy of management, Journal of Accounting and Finance, 4(2): 91-112. 
TORRES-REYNA, O. 2007. Panel data analysis: fixed and random effects using Stata (v 4.2). [Online]. Princeton University. Available at https://dss.princeton.edu/training [Accessed: 2018, September 15].

WOOLDRIDGE JEFFREY, M. 2015. Introductory Econometrics: A modern approach. Ontario: Nelson Education. 